\title{
Absolute B cell counts in blood predict long-term response in follicular lymphoma patients treated with rituximab without chemotherapy
}

\author{
Henna-Riikka Junlén ${ }^{1,2} \cdot$ Sandra Lockmer ${ }^{1,2} \cdot$ Eva Kimby $^{1} \cdot$ Björn Engelbrekt Wahlin ${ }^{1,2}$ (iD
}

Received: 4 June 2020 / Accepted: 27 July 2020 / Published online: 17 August 2020

(C) The Author(s) 2020

\begin{abstract}
Rituximab monotherapy is widely used for follicular lymphoma. However, there are no established predictors for response or response duration. We analyzed the long-term prognostic relevance of pre-treatment absolute blood counts of lymphocytes with subsets and monocytes in 265 follicular lymphoma patients, uniformly treated with rituximab without chemotherapy, in two Nordic Lymphoma Group trials. There were 265 previously untreated, stage II-IV follicular lymphoma patients with a median follow-up of over 10 years. Absolute B cell counts $\geq$ median $\left(0.09 \times 10^{9} / \mathrm{L}\right)$ were an independent predictor for shorter time to next treatment or death (multivariable analysis $P=0.010)$. In univariate analysis, absolute monocyte counts $\geq$ median $\left(0.5 \times 10^{9} / \mathrm{L}\right.$ ) did not correlate with time to next treatment or death, but with inferior overall survival $(P=0.034)$. Absolute $\mathrm{T}$ cell or $\mathrm{T}$ cell subset counts were not predictive for outcome. High absolute B cell counts, possibly reflecting circulating lymphoma cells, have an unfavorable impact on time to next treatment or death in patients treated with rituximab without chemotherapy.
\end{abstract}

Keywords Follicular lymphoma $\cdot$ Rituximab $\cdot$ B cell $\cdot$ Monocyte $\cdot$ Lymphocyte

$\begin{array}{ll}\text { List of abbreviations } \\ \text { B2M } & \beta_{2} \text {-microglobulin } \\ \text { FL } & \text { Follicular lymphoma } \\ \text { FLIPI } & \text { Follicular Lymphoma International Prognostic Index } \\ \text { IFN } & \text { Interferon- } \alpha 2 \mathrm{a} \\ \text { LDH } & \text { Lactate dehydrogenase } \\ \text { NLG } & \text { Nordic Lymphoma Group } \\ \text { OS } & \text { Overall survival } \\ \text { PFS } & \text { Progression-free survival } \\ \text { UNL } & \text { Upper normal limit } \\ \text { TNT } & \text { Time to next treatment or death } \\ \text { WHO } & \text { World Health Organization }\end{array}$

Björn Engelbrekt Wahlin bjorn.wahlin@sll.se

1 Unit of Hematology, Department of Medicine, Karolinska Institutet, Huddinge, Stockholm, Sweden

2 Medicinsk enhet Hematologi, Tema Cancer, Karolinska University Hospital, Stockholm, Sweden

\section{Introduction}

Follicular lymphoma (FL) is the most common indolent nonHodgkin lymphoma, and it is characterized by a highly variable clinical course [1]. FL consists of clonal centrocytes and centroblasts on whose numbers the World Health Organization (WHO) allocates FL to grades 1, 2, and 3A [1]. Standard first-line treatment is rituximab alone or in combination with chemotherapy.

The Follicular Lymphoma International Prognostic Index (FLIPI) is the most common system for risk stratification of FL, also in the rituximab era [2, 3]. However, the FLIPI cannot guide the choice of therapy and better prognostic and predictive tools are needed. Non-malignant immune cells in the FL tumor microenvironment, supporting growth and survival of tumor cells and suppressing the antitumor immune response, also have prognostic relevance [4]. The host immune system is important for the clinical effect of therapy with the antiCD20 antibody rituximab, as the effect of rituximab is dependent on T cells, NK cells, and monocytes/macrophages [5, 6]. The absolute monocyte count in blood has been proposed as an indicator for the level of tumor-induced immunosuppression, and for use as a possible prognostic marker in FL and other lymphomas [7-11]. The absolute lymphocyte count has 
also been suggested to have prognostic value in FL [12-14] and other lymphomas [15-18].

In two Nordic Lymphoma Group (NLG) chemotherapyfree trials using rituximab, we have previously reported that higher relative $\mathrm{T}$ cell levels in blood and in diagnostic lymph nodes predict better outcome including time to next treatment or death (TNT) [5]. Also higher WHO FL grades (2-3A) seemed favorable in comparison to WHO FL grade 1 [19]. Here, we have assessed the prognostic value of absolute lymphocyte subset and monocyte counts.

\section{Methods}

The study cohort consists of 265 previously untreated FL patients with absolute lymphocyte count and absolute monocyte count available from routine blood cell counts taken prior to the start of first-line therapy. The patients were part of the total study population of 321 patients with indolent lymphoma (269 with FL, 27 with marginal zone lymphoma, 3 with lymphocytic lymphoma, and 22 with low-grade lymphoma not otherwise specified) participating in two consecutive randomized NLG trials M39035 (phase II, inclusion 1998-1999) [20] and ML16865 (phase III, inclusion 2002-2008) [21] with published data on long-term follow-up [22]. In these trials, patients received two cycles consisting of four doses of rituximab $375 \mathrm{mg} / \mathrm{m}^{2}$ and they were 1:1 randomized to the addition of interferon- $\alpha 2 \mathrm{a}$ (IFN). Diagnostic tumor biopsies were centrally reviewed according to the WHO Classification (FL grades 1-3A) [1], and bone marrow involvement was evaluated by the local pathologist. All patients were $\geq 18$ years old and had advanced (stage II-IV) disease, WHO performance status $0-2$, and indication for therapy due to symptomatic or progressive disease.

In the clinical trial protocols, pre-treatment flow-cytometry analysis of blood and bone marrow was recommended but not obligatory. Flow cytometry of blood and bone marrow was performed in 132 and 192, respectively, of the 265 patients, and data on both specimens was available in 114 subjects. The lymphocyte subsets were reported as percentages of the population within the mononuclear gate. B cells were defined as CD19+ cells (or CD20+, in a few cases where the CD19 analysis was missing), $\mathrm{T}$ cells as $\mathrm{CD} 3+$, helper $\mathrm{T}$ cells as CD4+, cytotoxic T cells as CD8+, and NK cells as CD56+. Detailed descriptions of the flow-cytometry analysis and central pathology review have been published earlier $[5,19]$.

The clinical trials were conducted in accordance with the Declaration of Helsinki and the national laws and regulations concerning clinical trials. Written informed consent was obtained from all study participants prior to the clinical trial enrollment. For the present analysis, we used clinical data from a recently published, ethically approved, follow-up study
[22]. The addition of IFN did not affect long-term outcome in the clinical trials [20-22].

\section{Statistical analysis}

TNT was calculated from the date of trial inclusion to the date of next anti-lymphoma therapy or death of any cause. Overall survival (OS) was calculated from the date of trial inclusion to the date of death. Associations with TNT and OS were estimated using the Kaplan-Meier method and the Cox proportional hazards analysis. The assumption of proportionality was checked using Schoenfeld's residuals. Correlations between variables were analyzed using the Mann-WhitneyWilcoxon, Spearman, Fisher's exact test, and logistic regression depending on the nature of the variables. The blood cell counts and the lymphocyte subsets were tested as continuous as well as binary variables (dichotomized by the median) and also divided into tertiles. WHO FL grades were analyzed as a binary variable: WHO FL grade 1 as one group and WHO FL grades 2 and $3 \mathrm{~A}$ as the second group, due to a low number of patients with WHO FL grade $3 \mathrm{~A}(N=13)$. Institutional upper normal limits (UNL) were used as cut-off values for lactate dehydrogenase (LDH), where we made an exploratory analysis of $\mathrm{LDH}$ as a three-group categorical variable $(\mathrm{LDH}<1 \times$ $\mathrm{UNL}, \mathrm{LDH} 1-1.49 \times \mathrm{UNL}$, and $\mathrm{LDH} \geq 1.50 \times \mathrm{UNL}$ ). All $P$ values are two-tailed and $P<0.05$ was considered significant. All statistical calculations were performed using Stata 14.2 (StataCorp, College Station, TX, USA).

\section{Results}

There were $265 \mathrm{FL}$ patients treated in first line with rituximab without chemotherapy in the two trials. The median age was 56 years, $51 \%$ were women, and $78 \%$ had intermediate or high-risk FLIPI (Table 1). Nineteen $(7.2 \%)$ of the patients had lymphocytosis $\left(>4 \times 10^{9} / \mathrm{L}\right)$ and $62(23.4 \%)$ lymphopenia $\left(<1.0 \times 10^{9} / \mathrm{L}\right)$ according to the current definitions of lymphocytosis and lymphopenia in adults [23]. Rituximab monotherapy was given to 146 patients and rituximab combined with IFN to 119. The median follow-up time for surviving patients was 10.6 years (range, $0.3-18.8$ years). The median TNT was 2.2 years, with 184 patients having received new therapy.

Absolute lymphocyte counts and absolute B cell counts were strongly associated with morphological bone-marrow involvement, and also with other markers for high tumor burden such as engagement of $>4$ nodal areas (Table 2 ) and Ann Arbor stage as an ordinal variable $(P<0.0005$ for both counts). Absolute lymphocyte counts and, particularly, absolute B cell counts correlated strongly with the relative B cell levels in bone marrow $(P=0.0003 ; P<0.0005$; Fig. 1$)$. Higher absolute monocyte counts were associated with elevated LDH (Table 2). Absolute monocyte counts also co-varied 
Table 1 Clinical characteristics and their relation to outcome

\begin{tabular}{|c|c|c|c|c|c|c|}
\hline \multirow[t]{2}{*}{ Variable } & \multirow[t]{2}{*}{$N$} & \multirow[t]{2}{*}{$\%$} & \multicolumn{2}{|l|}{ TNT } & \multicolumn{2}{|l|}{ OS } \\
\hline & & & $P$ & HR $(95 \%$ CI $)$ & $P$ & HR $(95 \% \mathrm{CI})$ \\
\hline Male sex & 129 & 48.7 & 0.75 & & 0.34 & \\
\hline Age $>60$ years & 84 & 31.7 & 0.23 & & 0.001 & $2.35(1.45-3.80)$ \\
\hline \multicolumn{7}{|l|}{ Median (range): 56 (23-82) years } \\
\hline Ann Arbor stage III-IV & 237 & 89.2 & 0.98 & & 0.17 & \\
\hline Involved nodal areas $>4$ & 155 & 58.5 & 0.36 & & 0.09 & $0.66(0.41-1.07)$ \\
\hline Hemoglobin $\leq 12 \mathrm{~g} / \mathrm{dL}$ & 49 & 18.5 & 0.52 & & 0.18 & \\
\hline $\mathrm{LDH}>\mathrm{UNL}$ & 74 & 27.9 & 0.0004 & $1.75(1.28-2.38)$ & 0.020 & $1.80(1.10-2.94)$ \\
\hline FLIPI intermediate risk & 104 & 39.3 & 0.13 & $1.35(0.91-2.01)$ & 0.70 & \\
\hline FLIPI high risk & 102 & 38.5 & 0.021 & $1.59(1.07-2.35)$ & 0.27 & \\
\hline Bone marrow involvement & 129 & 51.8 & 0.46 & & 0.47 & \\
\hline Bulky disease & 48 & 18.1 & 0.30 & & 0.56 & \\
\hline B symptoms & 69 & 26.0 & 0.022 & $1.44(1.05-1.98)$ & 0.09 & $1.54(0.93-2.55)$ \\
\hline WHO performance status $1-2$ & 68 & 25.7 & 0.08 & $1.34(0.97-1.84)$ & 0.0002 & $2.53(1.56-4.12)$ \\
\hline WHO grade 1 & 122 & 46.0 & 0.009 & $1.46(1.10-1.94)$ & 0.046 & $1.63(1.01-2.65)$ \\
\hline Elevated lymphocytes $\left(>4 \times 10^{9} / \mathrm{L}\right)$ & 19 & 7.2 & 0.008 & $1.96(1.19-3.23)$ & 0.19 & \\
\hline
\end{tabular}

$T N T$, time to next treatment or death; $O S$, overall survival; $H R$, hazard ratio; $C I$, confidence interval; $L D H$, lactate dehydrogenase; $U N L$, upper normal limit; FLIPI, Follicular Lymphoma International Prognostic Index; WHO, World Health Organization

positively with absolute lymphocyte counts $(P<0.0001)$, but not with absolute $\mathrm{B}$ cell counts or absolute $\mathrm{T}$ cell counts $(P=$ $0.07 ; P=0.56)$. Absolute $\mathrm{B}$ and $\mathrm{T}$ cell counts were also positively correlated $(P=0.0005)$.

\section{Lymphocytes and TNT}

Absolute lymphocyte counts $\geq$ median $\left(1.3 \times 10^{9} / \mathrm{L}\right)$ were associated with shorter TNT, median 2.0 versus 3.0 years $(P=$ 0.041; Table 3, Fig. 2a); tertiles also predicted TNT ( $P=$ 0.008). The negative impact of absolute lymphocyte counts was due to $\mathrm{B}$ but not $\mathrm{T}$ or NK cells, because patients with absolute $B$ cell counts $\geq$ median $\left(0.09 \times 10^{9} / \mathrm{L}\right)$ showed shorter TNT, median 1.9 versus 3.1 years (Table 3, Fig. 2b). Absolute $\mathrm{T}$ cell subset or NK cell counts did not predict outcome (Table 3). Relative T cell subset levels which in this material were previously shown be prognostic [5] were now outcompeted by the absolute B cell counts in multivariable analysis. The 19 patients with overt $\left(>4 \times 10^{9} / \mathrm{L}\right)$ lymphocytosis (median [range] $7.3[4.1-124.0] \times 10^{9} / \mathrm{L}$ ), showed inferior TNT (Table 1). The lymphocytosis was in all available cases $(n=14)$ due to elevated B cells. Also when these 19

Table 2 Associations between lymphocytes and monocytes and clinical variables

\begin{tabular}{|c|c|c|c|c|c|c|}
\hline \multirow[t]{2}{*}{ Variable } & \multicolumn{2}{|l|}{ ALC } & \multicolumn{2}{|l|}{$\mathrm{ABC}$} & \multicolumn{2}{|l|}{$\mathrm{AMC}$} \\
\hline & $P$ & OR $(95 \% \mathrm{CI})$ & $P$ & OR $(95 \% \mathrm{CI})$ & $P$ & OR $(95 \% \mathrm{CI})$ \\
\hline Ann Arbor stage III-IV & 0.089 & $1.78(0.92-3.44)$ & 0.175 & & 0.67 & \\
\hline Involved nodal areas $>4$ & 0.011 & $1.38(1.08-1.76)$ & 0.035 & $3.12(1.08-8.99)$ & 0.053 & $2.65(0.99-7.15)$ \\
\hline Hemoglobin $\leq 12$ g/dL & 0.89 & & 0.60 & & 0.73 & \\
\hline $\mathrm{LDH}>\mathrm{UNL}$ & 0.17 & & 0.22 & & 0.017 & $2.90(1.21-7.00)$ \\
\hline Bone marrow involvement & 0.0001 & $2.11(1.44-3.10)$ & 0.023 & $54.9(1.73-1739.3)$ & 0.12 & \\
\hline Bulky disease & 0.36 & & 0.67 & & 0.253 & \\
\hline B symptoms & 0.68 & & 0.60 & & 1.00 & \\
\hline WHO grade 1 & 0.60 & & 0.405 & & & 0.70 \\
\hline
\end{tabular}

$A L C$, absolute lymphocyte count; $O R$, odds ratio; $C I$, confidence interval; $A B C$, absolute B cell count; $A M C$, absolute monocyte count; $L D H$, lactate dehydrogenase; $U N L$, upper normal limit; $W H O$, World Health Organization 


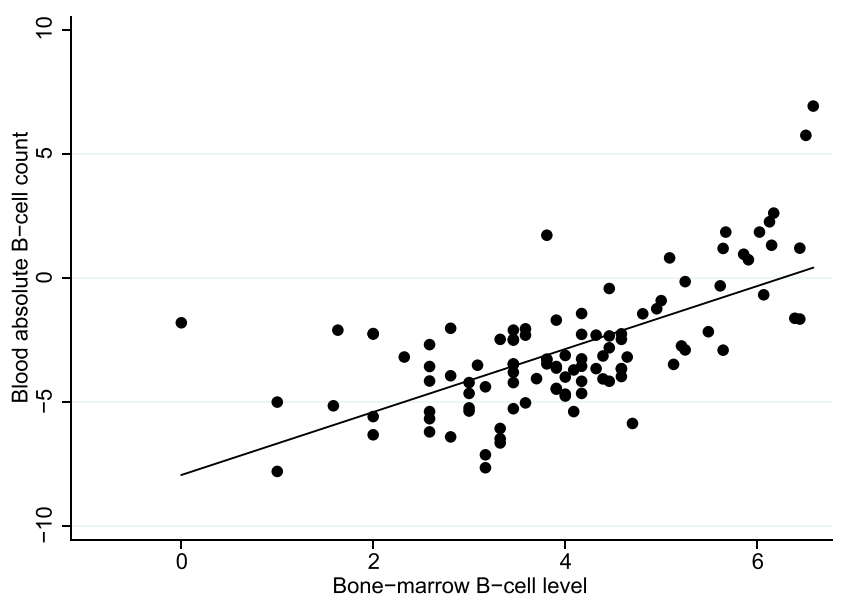

Fig. 1 Correlation of B cells in bone marrow and blood. Scatter plot of the correlation between flow cytometry-derived percentages of bonemarrow B cells and absolute B cell counts in blood. Both variables are log-transformed, base-2

patients were excluded from the analysis, absolute B cell counts remained significant for TNT $(P=0.011)$. Bonemarrow involvement or the relative levels of $\mathrm{B}$ cells in bone marrow did not correlate with TNT $(P=0.46 ; P=0.39)$.

Analysis of tertiles (cut-offs in Table 3 ) of absolute B cell counts showed that the adverse effect on TNT increased incrementally $(P=0.005$; Fig. 2 c). Patients with absolute B cell counts in the lowest tertile had median TNT of 3.3 years while those in the middle and the highest tertiles had 2.6 and 2.0 years respectively. Relative B cell levels in blood $\geq$ median $(7 \%)$ were also associated with inferior TNT $(P=0.013)$, but multivariable analysis showed that relative $\mathrm{B}$ cell levels were irrelevant when competing with absolute B cell counts. Absolute monocyte counts divided by the median $\left(0.5 \times 10^{9} /\right.$ L) and in tertiles were not significant for TNT (Table 3 ).

WHO FL grade 1 was associated with shorter TNT (Table 1; Fig. 3); patients with WHO grade 1 showed a median TNT of 2.0 years compared with 3.1 years in those with WHO grade 2-3A. WHO FL grade 1 also correlated with
Fig. 2 Outcome by lymphocytes and monocytes. Kaplan-Meier curves of time to next treatment or death by a absolute lymphocyte counts (ALC) divided by the median, $\mathbf{b}$ absolute $\mathrm{B}$ cell counts $(\mathrm{ABC}$ ) divided by the median, $\mathbf{c}$ ABC divided into tertiles, and of $\mathbf{d}$ overall survival by absolute monocyte counts (AMC) divided by the median

inferior OS ( $P=0.033$; Table 1; Fig. 3). The prognostic impact of high LDH was incremental, and particularly patients with $\mathrm{LDH} \geq 1.50 \times \mathrm{UNL}$ showed inferior TNT $(P=0.0001$; Fig. 3). The median TNT for this group was only 0.6 years while patients with LDH $1-1.49 \times \mathrm{UNL}$ and those with $\mathrm{LDH}$ $<$ UNL had median TNT of $2.1(P=0.023)$ and 2.7 years respectively. Also, OS was significantly shortened in the group with $\mathrm{LDH} \geq 1.50 \times \mathrm{UNL}(P=0.0001$; Fig. 3$)$. Fiveyear OS was $39 \%$ in those with $\mathrm{LDH} \geq 1.50 \times \mathrm{UNL}, 75 \%$ in the group with LDH $1-1.49 \times \mathrm{UNL}$, and $80 \%$ in patients with $\mathrm{LDH}<\mathrm{UNL}$. $\mathrm{LDH} \geq 1.50 \times \mathrm{UNL}$ was also significant in multivariable analysis for OS $(P=0.004)$. Elevated LDH outcompeted the FLIPI in the multivariable analysis for TNT.

In multivariable analysis with respect to TNT, absolute B cell counts $\geq$ median, WHO FL grade 1 , and $\mathrm{LDH}>\mathrm{UNL}$ were independent (Table 4). Absolute B cell counts predicted TNT both in patients treated with and without IFN (HR 1.6 and 2.1 respectively), although the reduced numbers decreased statistical significance $(P=0.13 ; P=0.007$, respectively).

\section{OS analysis}

Absolute lymphocyte or B cell counts had no impact on OS (Table 3). Absolute monocyte counts $\geq$ median were associated with inferior OS ( $P=0.036$; Table 3; Fig. $2 \mathrm{~d})$ in univariate but not in multivariable analysis (data not shown). Absolute monocyte counts in tertiles were not significant $(P=0.29)$. We also tested the different cut-off values for absolute monocyte counts used by others: $0.57 \times 10^{9} / \mathrm{L}$ [7], $0.34 \times 10^{9} / \mathrm{L}$ [24], and $0.63 \times$

Table 3 Distributions of lymphocytes and monocytes and their relations to TNT and OS

\begin{tabular}{|c|c|c|c|c|c|c|c|c|c|}
\hline \multirow[t]{2}{*}{ Variable } & \multirow[t]{2}{*}{$N$} & \multirow[t]{2}{*}{ Median } & \multirow[t]{2}{*}{ Range } & \multirow[t]{2}{*}{ p33 } & \multirow[t]{2}{*}{ p66 } & \multicolumn{2}{|l|}{ TNT } & \multicolumn{2}{|l|}{ OS } \\
\hline & & & & & & $P$ & HR $(95 \%$ CI) & $P$ & HR $(95 \%$ CI) \\
\hline $\mathrm{ALC} \times 10^{9} / \mathrm{L}$ & 265 & 1.3 & $0.31-124.0$ & 1.1 & 1.6 & 0.041 & $1.34(1.01-1.79)$ & 0.29 & $1.29(0.80-2.09)$ \\
\hline $\mathrm{ABC} \times 10^{9} / \mathrm{L}$ & 124 & 0.09 & $0.00-121.5$ & 0.05 & 0.18 & 0.003 & $1.89(1.25-2.86)$ & 0.16 & $1.65(0.82-3.31)$ \\
\hline $\mathrm{AMC} \times 10^{9} / \mathrm{L}$ & 265 & 0.50 & $0.07-3.7$ & 0.40 & 0.60 & 0.15 & $1.23(0.93-1.64)$ & 0.036 & $1.72(1.04-2.84)$ \\
\hline $\mathrm{CD} 3+\times 10^{9} / \mathrm{L}$ & 121 & 0.75 & $0.03-5.3$ & 0.50 & 0.98 & 0.93 & $1.02(0.68-1.54)$ & 0.21 & $1.57(0.77-3.18)$ \\
\hline $\mathrm{CD} 4+\times 10^{9} / \mathrm{L}$ & 115 & 0.45 & $0.02-2.7$ & 0.30 & 0.57 & 0.81 & $0.95(0.62-1.45)$ & 0.31 & $1.46(0.71-3.00)$ \\
\hline $\mathrm{CD} 8+\times 10^{9} / \mathrm{L}$ & 115 & 0.33 & $0.02-2.8$ & 0.24 & 0.45 & 0.22 & $1.30(0.85-1.99)$ & 0.08 & $1.96(0.93-4.13)$ \\
\hline $\mathrm{CD} 56+\times 10^{9} / \mathrm{L}$ & 97 & 0.24 & $0.02-4.1$ & 0.17 & 0.32 & 0.43 & $1.21(0.76-1.93)$ & 0.21 & $1.65(0.75-3.64)$ \\
\hline
\end{tabular}

$T N T$, time to next treatment or death; $O S$, overall survival; $H R$, hazard ratio; $C I$, confidence interval; $A L C$, absolute lymphocyte count; $A B C$, absolute B cell count; $A M C$, absolute monocyte count 
a

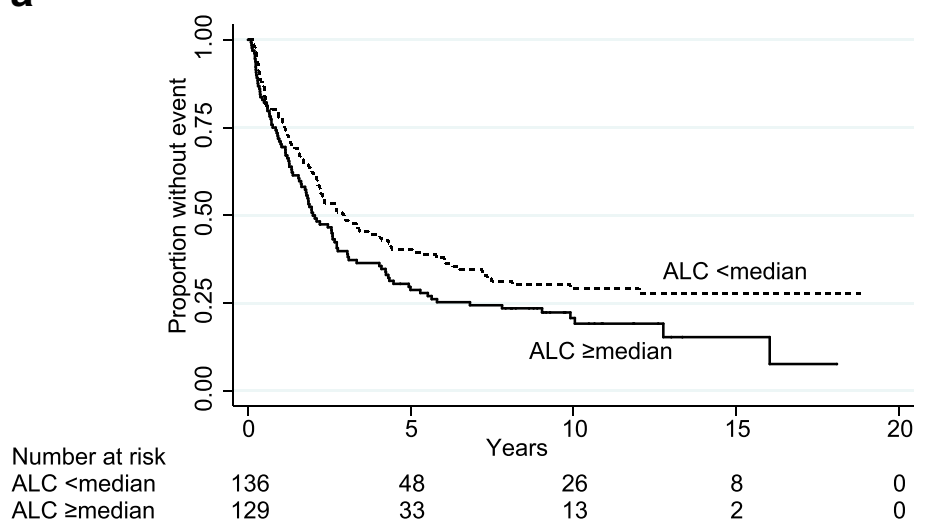

b

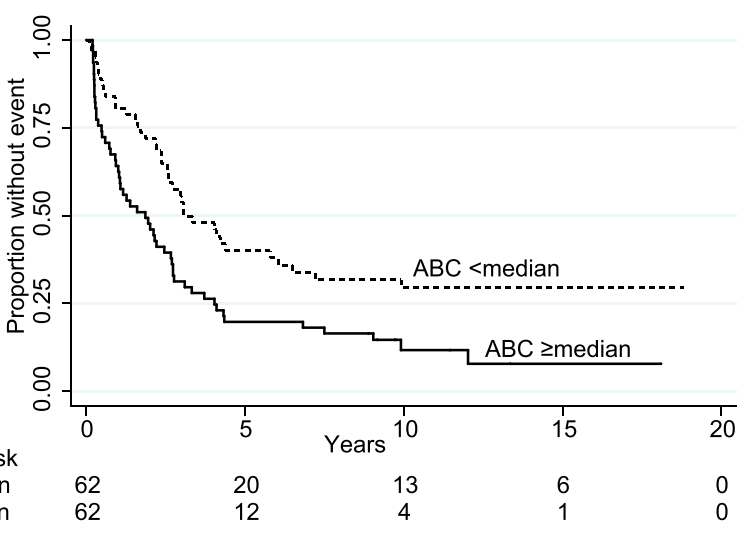

C

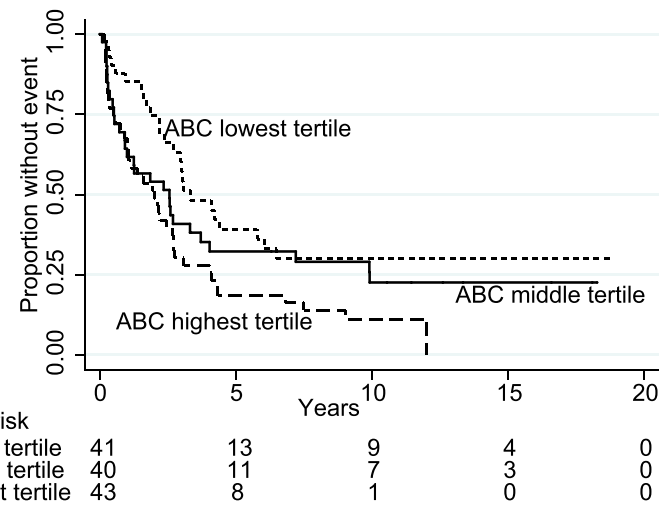

d

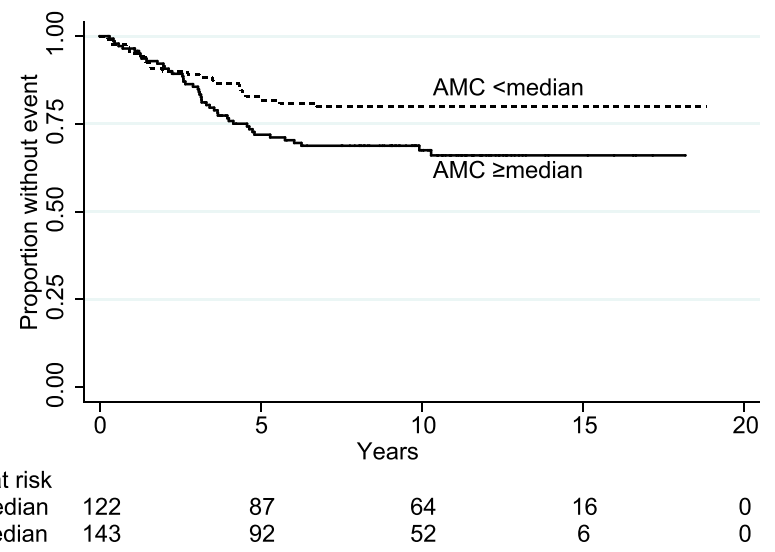


$10^{9} / \mathrm{L}$ [25] but found none of them prognostic for TNT or OS in our cohort (data not shown).

\section{Discussion}

In this analysis of FL patients, uniformly treated with rituximab without chemotherapy in two NLG trials and with long follow-up times (median 10.6 years), we show that higher pretreatment absolute lymphocyte counts correlate with shorter TNT and that this is wholly attributable to the absolute numbers of B cells. In multivariable analysis for TNT, absolute B cell counts were independent of other prognostic variables. Furthermore, absolute B cell counts were prognostic also when excluding patients with lymphocytosis.

Absolute B cell counts correlated strongly with B cell levels in the bone marrow (Fig. 1) and also with other markers of high tumor burden (stage, number of nodal stations, bonemarrow involvement). However, the markers of high tumor burden did not correlate with outcome and absolute B cell counts remained significant in multivariable analysis. High absolute B cell counts probably reflect circulating lymphoma cells, but we did not have information on clonality. PET/CT was not conducted in these trials, which would have been a more ideal method of assessing burden of disease.

In previous reports, low absolute lymphocyte counts before rituximab monotherapy have been associated with outcome in FL [12-14]. In patients receiving rituximab monotherapy, Behl et al. reported that pre-treatment absolute lymphocyte counts $<0.89 \times 10^{9} / \mathrm{L}$ (median of the study population) were associated with inferior treatment responses and shorter remissions [13], whereas Ghielmini et al. showed that pre-treatment absolute lymphocyte counts $<0.8 \times 10^{9} / \mathrm{L}$ predicted superior responses to rituximab induction [14]. In these studies, however, most patients had received previous chemotherapy, and in the study of Ghielmini et al. patients with mantle cell lymphoma were also included ( $\sim 30 \%)$. The cut-off values used by Behl et al. and Ghielmini et al. were not prognostic in our trials (data not shown).

Circulating lymphoma cells in FL are not heavily studied, and consistent criteria for defining peripheral blood involvement in FL are lacking [26]. Circulating lymphoma cells identified by morphology and/or flow cytometry and absolute neoplastic lymphocytosis (circulating lymphoma cells $>4 \times 10^{9} /$ L) have been investigated [26-28]. Studies in the rituximab era have shown that peripheral blood involvement has a negative impact on progression-free survival (PFS), time to progression, and TNT but no significant effect on OS [27-30]. In the study of Kodaira et al., leukemic presentation was defined by cytological identification of an abnormal lymphoid population in peripheral blood [29]. Maeshima et al. required $\geq 1 \%$ typical small-cleaved cells in the blood smear or positive flowcytometry results and $11 \%$ consecutive FL patients thus
Fig. 3 Outcome by follicular lymphoma grades and lactate dehydrogenase. Kaplan-Meier curves of time to next treatment or death by $\mathbf{a}$ follicular lymphoma grades and $\mathbf{b}$ lactate dehydrogenase (LDH) and of overall survival by $\mathbf{c}$ follicular lymphoma grades and $\mathbf{d} \mathrm{LDH}$

showed peripheral blood involvement, with significantly shorter progression-free survival after rituximab-containing therapy, while OS did not differ between the groups [27]. The levels of circulating lymphoma cells were highly variable (range, 2-92\%); notably, also low levels of circulating lymphoma cells predicted outcome, agreeing with our results [27]. It should be noted that we found absolute B cell counts to be prognostic also in patients with normal lymphocyte counts $(<$ $4 \times 10^{9} / \mathrm{L}$ ), suggesting that small amounts of circulating malignant cells could be detrimental when treating patients with rituximab, and that they would not be identified via standard blood chemistry. Sarkozy et al. identified 37 patients with leukemic disease ( $7.4 \%$ of all), detected by blood smear analysis and confirmed by flow cytometry, and showed inferior outcome compared with matched patients without peripheral blood involvement. These results were also validated in the PRIMA cohort [28], in which the presence of circulation lymphoma cells was assessed prospectively by the local laboratories, but the technical modalities used for detection were not pre-specified. In a subsequent study of the PRIMA cohort, Sarkozy et al. also showed that the negative impact of peripheral blood involvement on PFS and TNT was obviated with rituximab maintenance [30]. Rituximab dosing and the length of maintenance therapy might be of particular importance in patients with peripheral blood involvement as high level of circulating B cells at baseline and bone-marrow involvement have, in some studies, been associated with lower rituximab concentrations and inferior treatment outcomes in FL [31, 32].

In our cohort, high absolute monocyte counts were associated with shorter OS in univariate but not multivariable analysis. Furthermore, absolute monocyte counts were not prognostic when divided into tertiles. There was no significant association between absolute monocyte counts $\geq$ median and TNT, why we also tested the different cut-off values used by others: $0.57 \times 10^{9} / \mathrm{L}[7], 0.34 \times 10^{9} / \mathrm{L}[24]$, and $0.63 \times 10^{9} / \mathrm{L}$ [25] but found none of them prognostic for neither TNT nor OS. Wilcox et al. first demonstrated that higher absolute monocyte count at diagnosis was an independent predictor for poor OS in a heterogeneous cohort of FL patients, of whom $25 \%$ received rituximab containing therapy and $45 \%$ were initially observed [7]. In a subgroup analysis of patients with immediate treatment indication, no association between higher absolute monocyte count and OS was found [7]. The results from subsequent studies on the prognostic significance of absolute monocyte counts (at diagnosis) in FL patients treated with immunochemotherapy, are conflicting [24, 25]. Patient selection and treatment regimens may explain the 
a

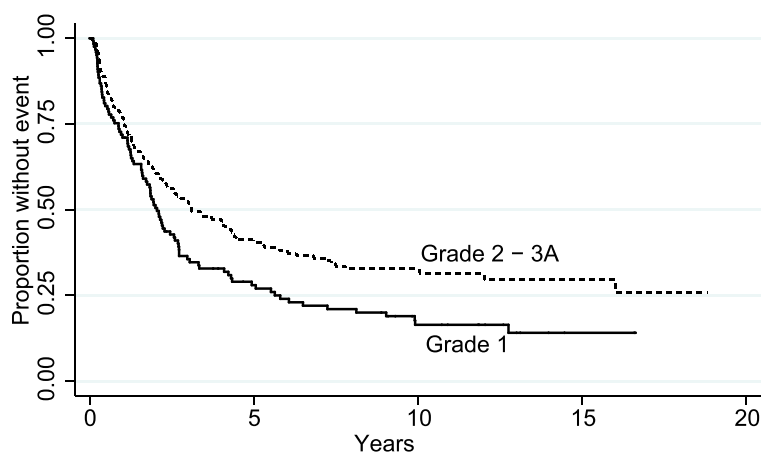

Number at risk Grade 2 - 3A Grade 1

$\begin{array}{lllll}143 & 53 & 26 & 8 & 0 \\ 122 & 28 & 13 & 2 & 0\end{array}$

b

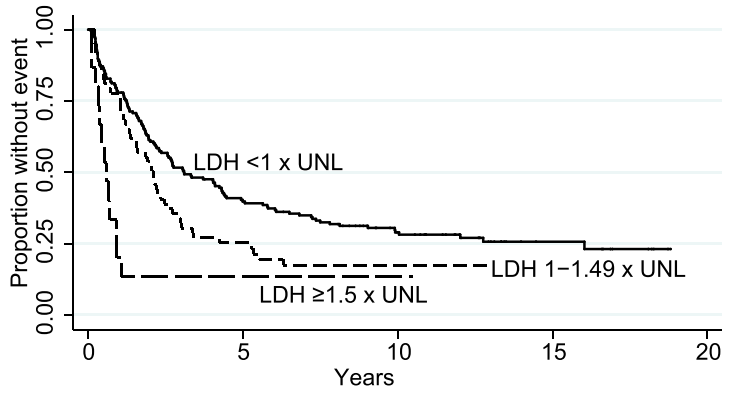

Number at risk LDH $<1 \times$ UNL LDH $\geq 1.5 \times$ UNL $\quad 15$

$\begin{array}{cccc}66 & 36 & 10 & 0 \\ 13 & 2 & 0 & 0 \\ 2 & 1 & 0 & 0\end{array}$

C

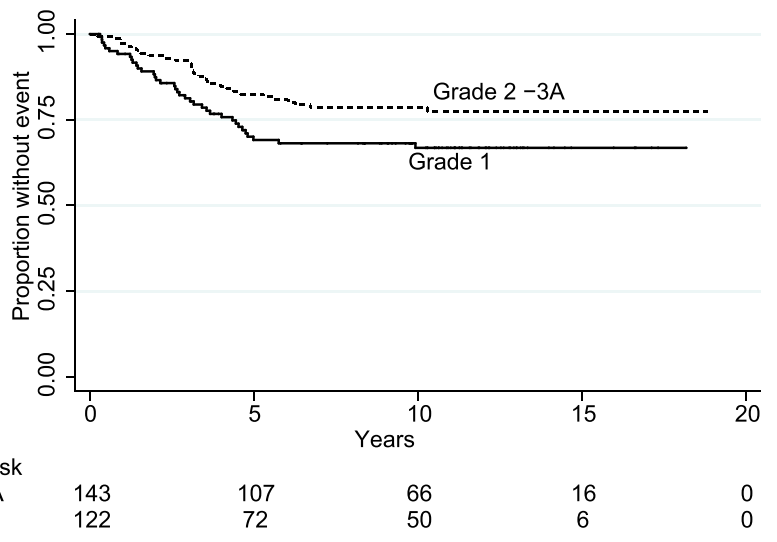

d

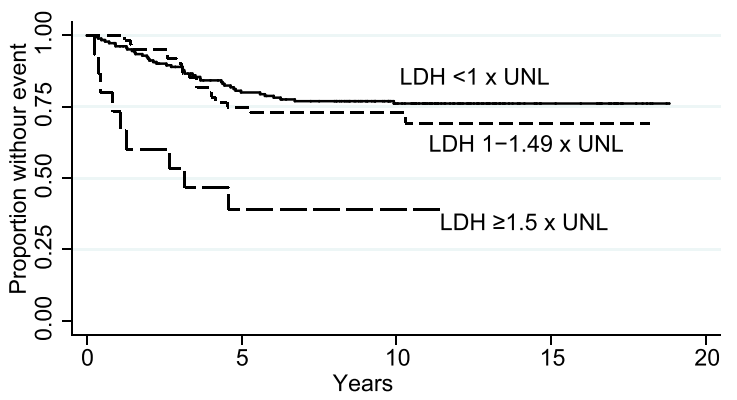

Number at risk $\mathrm{LDH}<1 \times$ UNL

LDH $1-1.49 \times$ UNL $\mathrm{LDH} \geq 1.5 \times$ UNL

$\begin{array}{lr}187 & 132 \\ 63 & 42 \\ 15 & 5\end{array}$

$\begin{array}{cc}132 & 91 \\ 42 & 22 \\ 5 & 3\end{array}$

$\begin{array}{cc}21 & 0 \\ 1 & 0 \\ 0 & 0\end{array}$


contradictory results of these studies. We do not think that absolute monocyte counts at initiation of rituximab therapy are of independent prognostic value.

Press et al. have previously suggested a laboratory testbased prognostic model consisting of LDH and $\beta_{2}$-microglobulin in patients treated with immunochemotherapy or chemotherapy followed by radioimmunotherapy, with an optimal cut-off point for LDH (and $\beta_{2}$-microglobulin) of $150 \%$ of the UNL [33]. We investigated this cut point in our patient population, and the group with $\mathrm{LDH} \geq 1.50 \times \mathrm{UNL}$ had very short TNT (median 0.6 years) and inferior OS which makes rituximab without chemotherapy an inappropriate choice of first-line therapy for this category. For this report we did not have $\beta_{2}$-microglobulin levels, but based on our LDH results and those shown for $\beta_{2}$-microglobulin in the PRIMA-PI [34], we plan to use $\mathrm{LDH} \geq 1.50 \times \mathrm{UNL}$ and $\beta_{2}$-microglobulin > $3 \mathrm{mg} / \mathrm{L}$ for stratification in future NLG trials.

The main strengths of the present analysis are the large sample size of FL patients uniformly treated with rituximab without chemotherapy, the long follow-up times, and additional information on lymphocyte subsets by the use of flow cytometry. We did not have flow cytometry profiles on all patients, which limits the assessment of the simultaneous impact of lymphocyte subsets and other factors on the outcome. Yet, neither outcome measures nor other prognostic variables differed significantly between those with available flow cytometry profiles and those with missing flow cytometry. Furthermore, markers for clonality or CD10 were not available, which makes it possible that these excess circulating B cells are non-malignant. However, the strong co-variations between absolute $\mathrm{B}$ cell counts and bone-marrow $\mathrm{B}$ cell levels (and morphological bone-marrow involvement) support our assumption that the peripheral B cells are mostly malignant. Since the exclusion of patients with lymphocytosis did not change the main results, even small numbers of circulating B cells appear deleterious for outcome.

In conclusion, we found that higher pre-treatment absolute $\mathrm{B}$ cell counts in blood were independently associated with shorter TNT in FL patients treated with rituximab without chemotherapy. Thus, treatment with rituximab in

Table 4 Multivariable analysis with respect to TNT

\begin{tabular}{lccc}
\hline Independent variable & HR & $95 \% \mathrm{CI}$ & $P$ value \\
\hline ABC above the median $\left(0.09 \times 10^{9} / \mathrm{L}\right)$ & 1.73 & $1.14-2.63$ & 0.010 \\
WHO grade 1 & 1.66 & $1.10-2.52$ & 0.017 \\
LDH $>$ UNL & 2.19 & $1.39-3.44$ & 0.001 \\
\hline
\end{tabular}

Competing, insignificant variables: B symptoms and WHO performance status

$T N T$, time to next treatment; $H R$, hazard ratio; $C I$, confidence interval; $A B C$, absolute B cell count; $W H O$, World Health Organization; $L D H$, lactate dehydrogenase; $U N L$, upper normal limit conventional doses appears insufficient for FL patients with higher absolute B cell counts. The negative prognostic impact of higher absolute B cell counts, also in small amounts, likely reflects the impact of circulating lymphoma cells. Studies with more detailed flow cytometry markers and on patients receiving chemoimmunotherapy are needed to further explore these cells and their prognostic/predictive properties in FL.

Acknowledgments The authors thank all the participants (patients and caregivers) in the Nordic Lymphoma Group-trials M39035 and ML16865.

Authors' contributions HRJ analyzed and interpreted data, SL collected data, EK planned the study and collected data, and BEW planned the study and collected, analyzed, and interpreted data. All authors wrote, read, and approved the final manuscript for publication.

Funding information Open access funding provided by Karolinska Institute. This study was funded by Stockholm County Council (clinical research appointment), Cancerfonden, Svenska Läkaresällskapet and Svenska Sällskapet för Medicinsk Forskning (SSMF).

Data availability The datasets used during the current study are available from the corresponding author on reasonable request.

\section{Compliance with ethical standards}

Ethics approval and consent to participate All procedures performed in the trials were in accordance with the ethical standards of the institutional and national research committees and with the 1964 Helsinki declaration and its later amendments. Informed consent was obtained from all individual participants enrolled in the trials. Clinical follow-up data was obtained from an ethically approved, recently published follow-up study.

Consent for publication Not applicable.

Competing interests BEW has been a consultant for Roche. EK has previously got research funds from Roche, but not for this project. H$\mathrm{RJ}$ and SL declare no conflicts of interest.

Open Access This article is licensed under a Creative Commons Attribution 4.0 International License, which permits use, sharing, adaptation, distribution and reproduction in any medium or format, as long as you give appropriate credit to the original author(s) and the source, provide a link to the Creative Commons licence, and indicate if changes were made. The images or other third party material in this article are included in the article's Creative Commons licence, unless indicated otherwise in a credit line to the material. If material is not included in the article's Creative Commons licence and your intended use is not permitted by statutory regulation or exceeds the permitted use, you will need to obtain permission directly from the copyright holder. To view a copy of this licence, visit http://creativecommons.org/licenses/by/4.0/.

\section{References}

1. Swerdlow SH, Campo E, Harris NL, Jaffe ES, Pileri SA, Stein H (2008) WHO classification of tumours of haematopoietic and lymphoid tissues. IARC Press, Lyon 
2. Solal-Celigny P, Roy P, Colombat P, White J, Armitage JO, Arranz-Saez R, Au WY, Bellei M, Brice P, Caballero D, Coiffier B, Conde-Garcia E, Doyen C, Federico M, Fisher RI, GarciaConde JF, Guglielmi C, Hageenbeek A, Haioun C, LeBlanc M, Lister AT, Lopez-Guillermo A, McLaughlin P, Milpied N, Morel P, Mounier N, Proctor SJ, Rohatiner A, Smith P, Soubeyran P, Tilly H, Vitolo U, Zinzani PL, Zucca E, Montserrat E (2004) Follicular Lymphoma International Prognostic Index. Blood 104(5):1258 1265. https://doi.org/10.1182/blood-2003-12-4434

3. Buske C, Hoster E, Dreyling M, Hasford J, Unterhalt M, Hiddemann W (2006) The Follicular Lymphoma International Prognostic Index (FLIPI) separates high-risk from intermediateor low-risk patients with advanced-stage follicular lymphoma treated front-line with rituximab and the combination of cyclophosphamide, doxorubicin, vincristine, and prednisone (R-CHOP) with respect to treatment outcome. Blood 108(5):1504-1508

4. Sugimoto T, Watanabe T (2016) Follicular lymphoma: the role of the tumor microenvironment in prognosis. J Clin Exp Hematop 56(1):1-19. https://doi.org/10.3960/jslrt.56.1

5. Wahlin BE, Sundstrom C, Holte H, Hagberg H, Erlanson M, Nilsson-Ehle H, Linden O, Nordstrom M, Ostenstad B, Geisler $\mathrm{CH}$, Brown Pde N, Lehtinen T, Maisenholder M, Tierens AM, Sander B, Christensson B, Kimby E (2011) T cells in tumors and blood predict outcome in follicular lymphoma treated with rituximab. Clin Cancer Res 17(12):4136-4144. https://doi.org/10.1158/ 1078-0432.CCR-11-0264

6. Cartron G, Watier H, Golay J, Solal-Celigny P (2004) From the bench to the bedside: ways to improve rituximab efficacy. Blood 104(9):2635-2642

7. Wilcox RA, Ristow K, Habermann TM, Inwards DJ, Micallef IN, Johnston PB, Colgan JP, Nowakowski GS, Ansell SM, Witzig TE, Markovic SN, Porrata L (2012) The absolute monocyte count is associated with overall survival in patients newly diagnosed with follicular lymphoma. Leuk Lymphoma 53(4):575-580. https://doi. org/10.3109/10428194.2011.637211

8. Tadmor T, Bari A, Sacchi S, Marcheselli L, Liardo EV, Avivi I, Benyamini N, Attias D, Pozzi S, Cox MC, Baldini L, Brugiatelli M, Federico M, Polliack A (2014) Monocyte count at diagnosis is a prognostic parameter in diffuse large B-cell lymphoma: results from a large multicenter study involving 1191 patients in the preand post-rituximab era. Haematologica 99(1):125-130. https://doi. org/10.3324/haematol.2013.088161

9. von Hohenstaufen KA, Conconi A, de Campos CP, Franceschetti S, Bertoni F, Margiotta Casaluci G, Stathis A, Ghielmini M, Stussi G, Cavalli F, Gaidano G, Zucca E (2013) Prognostic impact of monocyte count at presentation in mantle cell lymphoma. $\mathrm{Br} \mathrm{J}$ Haematol 162(4):465-473. https://doi.org/10.1111/bjh.12409

10. Yang YQ, Liang JH, Wu JZ, Wang L, Qu XY, Cao L, Zhao XL, Huang DP, Fan L, Li JY, Xu W (2016) Elevated absolute monocyte count predicts unfavorable outcomes in patients with angioimmunoblastic T-cell lymphoma. Leuk Res 42:88-92. https://doi.org/10.1016/j.leukres.2015.12.010

11. Huang JJ, Li YJ, Xia Y, Wang Y, Wei WX, Zhu YJ, Lin TY, Huang HQ, Jiang WQ, Li ZM (2013) Prognostic significance of peripheral monocyte count in patients with extranodal natural killer/ T-cell lymphoma. BMC Cancer 13:222. https://doi.org/10.1186/ 1471-2407-13-222

12. Siddiqui M, Ristow K, Markovic SN, Witzig TE, Habermann TM, Colgan JP, Inwards DJ, White WL, Ansell SM, Micallef IN, Johnston PB, Call TG, Porrata LF (2006) Absolute lymphocyte count predicts overall survival in follicular lymphomas. Br J Haematol 134(6):596-601

13. Behl D, Ristow K, Markovic SN, Witzig TE, Habermann TM, Colgan JP, Inwards DJ, White WL, Ansell SM, Micallef IN, Johnston PB, Porrata LF (2007) Absolute lymphocyte count predicts therapeutic efficacy of rituximab therapy in follicular lymphomas. Br J Haematol 137(5):409-415. https://doi.org/10. 1111/j.1365-2141.2007.06596.x

14. Ghielmini M, Rufibach K, Salles G, Leoncini-Franscini L, LegerFalandry C, Cogliatti S, Fey M, Martinelli G, Stahel R, Lohri A, Ketterer N, Wernli M, Cerny T, Schmitz SF (2005) Single agent rituximab in patients with follicular or mantle cell lymphoma: clinical and biological factors that are predictive of response and eventfree survival as well as the effect of rituximab on the immune system: a study of the Swiss Group for Clinical Cancer Research (SAKK). Ann Oncol 16(10):1675-1682

15. Hasenclever D, Diehl V (1998) A prognostic score for advanced Hodgkin's disease. International Prognostic Factors Project on Advanced Hodgkin's Disease. N Engl J Med 339(21):1506-1514. https://doi.org/10.1056/nejm199811193392104

16. Kim DH, Baek JH, Chae YS, Kim YK, Kim HJ, Park YH, Song HS, Chung JS, Hyun MS, Sohn SK (2007) Absolute lymphocyte counts predicts response to chemotherapy and survival in diffuse large B-cell lymphoma. Leukemia 21(10):2227-2230. https://doi. org/10.1038/sj.leu.2404780

17. Castillo JJ, Morales D, Quinones P, Cotrina E, Desposorio C, Beltran B (2010) Lymphopenia as a prognostic factor in patients with peripheral T-cell lymphoma, unspecified. Leuk Lymphoma 51(10):1822-1828. https://doi.org/10.3109/10428194.2010. 508189

18. Mitrovic Z, Perry AM, Suzumiya J, Armitage JO, Au WY, Coiffier B, Holte H, Jaffe ES, Monserrat E, Rajan SK, Savage KJ, Tobinai K, Vose JM, Weisenburger DD (2012) The prognostic significance of lymphopenia in peripheral T-cell and natural killer/T-cell lymphomas: a study of 826 cases from the International Peripheral Tcell Lymphoma Project. Am J Hematol 87(8):790-794. https://doi. org/10.1002/ajh.23205

19. Wahlin BE, Sundstrom C, Sander B, Christensson B, JeppssonAhlberg A, Hjalmarsson E, Holte H, Ostenstad B, Brown PD, Smeland EB, Kimby E (2014) Higher World Health Organization grades of follicular lymphoma correlate with better outcome in two Nordic Lymphoma Group trials of rituximab without chemotherapy. Leuk Lymphoma 55(2):288-295. https://doi.org/10.3109/ 10428194.2013.802778

20. Kimby E, Jurlander J, Geisler C, Hagberg H, Holte H, Lehtinen T, Ostenstad B, Hansen M, Osterborg A, Linden O, Sundstrom C (2008) Long-term molecular remissions in patients with indolent lymphoma treated with rituximab as a single agent or in combination with interferon alpha-2a: a randomized phase II study from the Nordic Lymphoma Group. Leuk Lymphoma 49(1):102-112. https://doi.org/10.1080/10428190701704647

21. Kimby E, Ostenstad B, Brown P, Hagberg H, Erlanson M, Holte H, Linden O, Johansson AS, Ahlgren T, Wader K, Wahlin BE, Delabie J, Sundstrom C (2015) Two courses of four weekly infusions of rituximab with or without interferon-alpha2a: final results from a randomized phase III study in symptomatic indolent B-cell lymphomas. Leuk Lymphoma 1-10. https://doi.org/10.3109/ 10428194.2015.1014363

22. Lockmer S, Ostenstad B, Hagberg H, Holte H, Johansson AS, Wahlin BE, Wader KF, Steen CB, Meyer P, Maisenholder M, Smedby KE, Brown P, Kimby E (2018) Chemotherapy-free initial treatment of advanced indolent lymphoma has durable effect with low toxicity: results from two Nordic Lymphoma Group trials with more than 10 years of follow-up. J Clin Oncol JCO1800262. https://doi.org/10.1200/JCO.18.00262

23. Mims MP (2018) Lymphocytosis, lymphocytopenia, hypergammaglobulinemia, and hypogammaglobulinemia. In: EJB RH Jr, Silberstein LE, Heslop H, Weitz J, Anastasi J (eds) Hematology, basic principles and practice, 7 th edn. Churchill Livingstone/Elsevier, Philadelphia, pp 682-690

24. Watanabe R, Tomita N, Kishimoto K, Koyama S, Ogusa E, Ishii Y, Miyashita K, Matsuura S, Fujisawa S, Hattori Y, Takasaki H, Fujita 
A, Ohshima R, Kuwabara H, Hashimoto C, Fujimaki K, Sakai R, Ishigatsubo Y (2013) Absolute monocyte count in follicular lymphoma patients treated with rituximab plus cyclophosphamide, doxorubicin, vincristine, and prednisone. Leuk Res 37(10):12081212. https://doi.org/10.1016/j.leukres.2013.07.015

25. Marcheselli L, Bari A, Anastasia A, Botto B, Puccini B, Dondi A, Carella AM, Alvarez I, Chiarenza A, Arcari A, Salvi F, Federico M (2015) Prognostic roles of absolute monocyte and absolute lymphocyte counts in patients with advanced-stage follicular lymphoma in the rituximab era: an analysis from the FOLL05 trial of the Fondazione Italiana Linfomi. Br J Haematol 169(4):544-551. https://doi.org/10.1111/bjh.13332

26. Beltran BE, Quiñones P, Morales D, Alva JC, Miranda RN, Lu G, Shah BD, Sotomayor EM, Castillo JJ (2013) Follicular lymphoma with leukemic phase at diagnosis: a series of seven cases and review of the literature. Leuk Res 37(9):1116-1119. https://doi.org/10. 1016/j.leukres.2013.05.016

27. Maeshima AM, Taniguchi H, Tanioka K, Kitahara H, Miyamoto K, Fukuhara S, Munakata W, Suzuki T, Maruyama D, Kobayashi Y, Tobinai K, Kushima R (2015) Clinicopathological characteristics of follicular lymphoma with peripheral blood involvement. Leuk Lymphoma 56(7):2000-2004. https://doi.org/10.3109/10428194. 2014.963578

28. Sarkozy C, Baseggio L, Feugier P, Callet-Bauchu E, Karlin L, Seymour JF, Lebras L, Michallet AS, Offner F, Dumas O, Traverse-Glehen A, Ffrench M, Lopez-Guillermo A, Berger F, Coiffier B, Felman P, Salles G (2014) Peripheral blood involvement in patients with follicular lymphoma: a rare disease manifestation associated with poor prognosis. Br J Haematol 164(5):659667. https://doi.org/10.1111/bjh.12675

29. Kodaira M, Takeuchi K, Nara E, Nakano K, Ueda K, Yamada S, Mishima Y, Yokoyama M, Terui Y, Hatake K (2009) Leukemic presentation is predictive indicator for relapse for patients with follicular lymphoma treated with rituximab containing initial therapy. Paper presented at the ASH Annual Meeting Abstracts, Dec 05-08

30. Sarkozy C, Seymour JF, Ferme C, Caballero D, Ghesquieres H, Leppa S, Delarue R, Pedersen LM, Mounier C, Gomes Da Silva M, Chassagne-Clement C, Maerevoet M, Salles G (2014)
Rituximab maintenance obviates the poor prognosis associated with circulating lymphoma cells in patients with follicular lymphoma. Blood 123(17):2740-2742. https://doi.org/10.1182/blood-2014$02-553693$

31. Berinstein NL, Grillo-Lopez AJ, White CA, Bence-Bruckler I, Maloney D, Czuczman M, Green D, Rosenberg J, McLaughlin P, Shen D (1998) Association of serum rituximab (IDEC-C2B8) concentration and anti-tumor response in the treatment of recurrent low-grade or follicular non-Hodgkin's lymphoma. Ann Oncol 9(9):995-1001

32. Jager U, Fridrik M, Zeitlinger M, Heintel D, Hopfinger G, Burgstaller S, Mannhalter C, Oberaigner W, Porpaczy E, Skrabs C, Einberger C, Drach J, Raderer M, Gaiger A, Putman M, Greil R, Arbeitsgemeinschaft Medikamentose Tumortherapie I (2012) Rituximab serum concentrations during immuno-chemotherapy of follicular lymphoma correlate with patient gender, bone marrow infiltration and clinical response. Haematologica 97(9):1431-1438. https://doi.org/10.3324/haematol.2011.059246

33. Press OW, Unger JM, Rimsza LM, Friedberg JW, LeBlanc M, Czuczman MS, Kaminski M, Braziel RM, Spier C, Gopal AK, Maloney DG, Cheson BD, Dakhil SR, Miller TP, Fisher RI (2013) A comparative analysis of prognostic factor models for follicular lymphoma based on a phase III trial of CHOP-rituximab versus CHOP + 131iodine-tositumomab. Clin Cancer Res 19(23):6624-6632. https://doi.org/10.1158/1078-0432.ccr-131120

34. Bachy E, Maurer MJ, Habermann TM, Gelas-Dore B, MaucortBoulch D, Estell JA, Van den Neste E, Bouabdallah R, Gyan E, Feldman AL, Bargay J, Delmer A, Slager SL, Gomes da Silva M, Fitoussi O, Belada D, Maisonneuve H, Intragumtornchai T, Ansell SM, Lamy T, Dartigues P, Link BK, Seymour JF, Cerhan JR, Salles G (2018) A simplified scoring system in de novo follicular lymphoma treated initially with immunochemotherapy. Blood 132(1):4958. https://doi.org/10.1182/blood-2017-11-816405

Publisher's note Springer Nature remains neutral with regard to jurisdictional claims in published maps and institutional affiliations. 